Youhanna Nessim Youssef

Brisbane

Australian Catholic University

Youhanna.Youssef@acu.edu.au

\title{
COPTIC AND COPTO-ARABIC LITURGICAL TEXTS RELATING TO MICHAEL THE NEW MARTYR
}

\author{
Michael the New \\ IN THE MEMENTO $S_{\text {ANCTORUM }}$
}

The Coptic Church commemorates in the Memento Sactorum of the Psalmodia two new martyrs called Michael:

1) Michael the Hegumen from Tukh who suffered martyrdom on 30 Kiahk 1240 AM (AD 1523). ${ }^{1}$ He lived during the Mameluk era, during the patriarchate of Gabriel V.

2) Michael the Monk from Damietta who was consecrated in the Monastery of Saint John (the Little?). At one time on his way to Cairo, he renounced his faith and consecration as a monk and married a Muslim woman. After eight days he repented and confessed his faith in front of the king who ordered that his body be burned. He is commemorated in the Antiphonarion on 11 Hatour.

The New Martyr Michael - published below - is the one pertaining to a fragment that survived in the Monastery of Saint Macarius. ${ }^{2}$ Our texts show that the cult of Michael survived at least until the seventeenth century, as we have the psalis written by Nicodemus. ${ }^{3}$

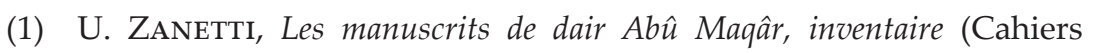
d'Orientalisme, 11), Genève, 1986, p. 61, Numéro 408 (Hag. 42).

(2) Y. N. Youssef, "Michael, a New Martyr according to a Fragment from Saint Macarius Monastery," BSAC, 46 (2007), pp. 151-158.

(3) Y. N. Youssef, "Recherches d'hymnographie copte: Nicodème et Sarkis," OCP, 64 (1998), pp. 383-402; IDEM, "Nicodème auteur des psalies," OCP, 60 (1994), pp. 625-633. 


\section{THE IMPORTANCE OF THESE TEXTS}

In the year 1999, the late Nabih Kamel Daoud published a book about the history of the Church of the Virgin in Ma'adi where he referred to manuscripts in the Church's collection ${ }^{4}$ pertaining to the veneration of Michael the New. In his description of the church of Ma'adi, Otto Meinardus did not mention any relics; however, he mentioned that the northern sanctuary is dedicated to Saint Michael (without further precision). This could be an indication of the veneration of Michael the New ${ }^{5}$ that we will publish the liturgical texts related to him hereafter.

The Church in Ma'adi is known as al- 'Adawia. ${ }^{6}$

In his inventory of the relics of saints, Otto Meinardus did not include the relics of Michael. ${ }^{7}$

\section{THE MANUSCRIPT}

The description of the manuscript given by the catalogue of Delaporte is thus:

HYMNES ET PRIERES (bohairique).

$1 \mathrm{v}-19 \mathrm{v}$ Psallie, canons, doxologies et paraclèses en l'honneur des patriarches Abraham, Isaacet Jacob. 20r-71r. Hymnes pour le mois de Choiak et références, suivies de la traduction arabe. $73 \mathrm{v}-$ 224. Psallies acrostiches, Hymnes, etc. mélangées à de nombreuses pieces arabes.

Ms. De 225 feuillets 28x15. Daté (19r.) de l'an 1216 E.M. [1500 ap. J.C.]

Ce manuscrit est coté de 1à 224, y compris 139bis.

Texte mal écrit, par un mauvais copiste.

(4) N. K. DAOUD, تاريخ كنيسة السيدة العذراء بالمعادي [History of the Church of the Virgin in al-Ma'adi], Cairo, 1999, see the list of manuscripts on pp. 102-104; see the chapter for the fifteenth century on pp. 35-36.

(5) O. F. Meinardus, Christian Egypt Ancient and Modern, Cairo, 1977, p. 350 .

(6) S. TIMM, Das christlich-koptische Agypten in arabischer Zeit, Wiesbaden, 1984, S. 64-69.

(7) O. F. MeInARdus, Two Thousand Years of Coptic Christianity, Cairo, 2000, pp. 311-323; IDEM, Christian Egypt, Faith and Life, Cairo, 1970, pp. 141197. 
Acquis à Nikiou en 17=671, par Vansleb, dont le cachet sur cire est empreint au premier et au dernier feuillet - AA. 24. Regius, 339.

Invent. Copte $32 .{ }^{8}$

\section{HistoricAl CONTEXT}

\section{John XIII (1484-1524)}

The martyrdom of Michael took place during the patriarchate of John XIII which was a very difficult time for the Coptic Church. Only a few lines are dedicated to this patriarch in the Book of the History of the Patriarchs. $^{9}$

According to Labib, John XIII was a monk from Dayr alMuharraq. ${ }^{10}$

Labib's study of John shows that he was a good pastor. There are also recurring references to the era as being "bad times [sū' / fasād az-zamān]."11 During his papacy many Christians converted to Islam and this forced John XIII to be more flexible about laws regarding marriage. ${ }^{12}$

We possess another letter from Patriarch John XIII to his colleague Ignatius Nuh of Lebanon, Patriarch of Antioch and Syria (14941509). ${ }^{13}$ It is a letter of commendation for a Syrian priest named Ibrahim, who had been caught in the complexities of parallel Syrian Orthodox patriarchates: Ibrahim had been consecrated metropolitan of the town of al-Ma'dan by the Syrian Orthodox patriarch of Tur ' $A b$ din, and not by Patriarch Ignatius Nuh (of Antioch-Syria), who had

(8) L. Delaporte, Catalogue des manuscrits Coptes de la Bibliothèque Nationale de Paris, Paris, 1912, p. 81-82, no. 98.

(9) A. Khater and O. H. E. Burmester, History of the Patriarchs of the Egyptian Church Known as the History of the Holy Church, vol. 3, pt. 3 (Textes et documents, 13), Le Caire, 1970, fol. 257r, p. 159 (text), p. 274 (translation).

(10) S. Y. LABIB, "John XIII," in Coptic Encyclopaedia, vol. 4, ed. A. S. AтіYA. New York, 1991, pp. 1346-1347 (I was unable to find this information elsewhere).

(11) T. EL-LeITHY, Coptic Culture and Conversion in Medieval Cairo 12951524, Dissertation presented to the Faculty of Princeton University in Candidacy for the degree of Doctor of Philosophy, January 2005, p. 379 (unpublished).

(12) EL-LeITHY, Coptic Culture and Conversion, p. 372.

(13) I. BCHEIRY, "Lettera del patriarca copto Yuhanna XIII al patriarco siro Nuh Libanese," Parole de l'Orient, 30 (2005), pp. 384-409. 
consecrated his own candidate for the position. In his letter, Coptic Patriarch John attempts to give pastoral advice in the midst of a sensitive situation. John concedes that the patriarch of Tur 'Abdin had erred in consecrating a metropolitan for a town outside of his jurisdiction, and insists that the canon of Nicea - which stipulates that there cannot be two bishops for the same city - must be upheld. Yet he still gives Ibrahim his support, and hopes that Patriarch Ignatius Nuh can do so as well. ${ }^{14}$ In his letter, Patriarch John XIII invokes St. Severus of Antioch ${ }^{15}$ to remind his successor that the canons of the Church were always intended to be compassionate.

Patriarch John XIII was all too aware of "the great destruction, ruin and want in every place." Accordingly, the shepherds of Christian flocks were called to be forgiving, gracious, generous, longsuffering, slow to anger, merciful - so as to unite the community, and neither cause damage nor give anyone else the opportunity to do so. Their call was to lead and provide by example the "good" name of Christians in society. These are rather humble goals, rendered in language that is not particularly exalting or inspiring. Given the "difficulty of the time," however, they were appropriate. John's letter is a reminder of the quiet, humble, realistic leadership that helped the Coptic Orthodox Church through one of its most difficult periods. ${ }^{16}$

In the sixteenth century, the clerical leadership was largely intact, albeit weakened from the preceding Mamluk era. In correspondence with the Coptic congregation in Sammanud, Patriarch Yuhanna XIII revealed his vulnerability when reminding his flock that "archons do not control the Church. Instead, the Church has power over everyone. All affairs should be decided by the Church and not by the archons." 17

(14) The passage of the letter under consideration here is found in BCHEIRY, "Lettera del patriarca copto Yuhanna XIII," pp. 404-407 (paragraphs 38-40).

(15) The syndocal letters between the Egyptian and Syrian prelates always evoke the name of Severus (cf. Y. N. YOUSSEF, "The Quotations of Severus of Antioch in the Book of the Confessions of the Fathers," Ancient Near Eastern Studies, 40 (2003), pp. 178-229.

(16) M. N. SWANSON, The Coptic Papacy in Islamic Egypt - 641-1517 (The Popes of Egypt, 2), Cairo, New York, 2010, pp. 126-127.

(17) F. ARManios, Coptic Christianity in Ottoman Egypt, New York, 2011, p. 35. 
During the patriarchate of John XIII, we possess a note written by his own hand from the year 1506 in which he laments that the Monastery of St. Antony was "empty, deprived of inhabitants."18

A few years before the martyrdom of Michael, in 1488 AD, Patriarch John XIII translated the relics of Saint Mercurius to his church in Old Cairo. ${ }^{19}$

In the following decades, Salib suffered martyrdom in the year 1512 AD. ${ }^{20}$

Yuhanna XIII died in 1524, and community elders chose to bury him under Salib's newly-constructed shrine at the Church of the Virgin in Harat Zuwayla. ${ }^{21}$

\section{The Government}

The reign of the Burji Mamluk Sultan Qa'itbay (1468-1495) was not pleasant for Copts. He added many taxes that were deemed necessary for the wars he was engaged in. Rich Jews and Christians were remorselessly squeezed. ${ }^{22}$

The Islamic sources estimate that the sixteen campaigns conducted by Qa'itbay alone cost the country an enormous sum of $7,065,000$ dinars, at a time when the resources of the country were depleted by the successive plagues that brought down the working class everywhere. This situation recurred during the successive sultanates until the end of the Mamluk rule. ${ }^{23}$

(18) See M. SWANSON, "The Monastery of St. Paul, Historical Context" in The Cave Church of Paul the Hermit at the Monastery of Saint Paul, Egypt, ed. W. LySTER, New Haven, Cairo, 2008, pp. 52-53.

(19) M. SIMAIKA and Y. 'ABD AL-MASIH, Catalogue of the Coptic and Arabic Manuscripts in the Coptic Museum, the Patriarchate, the Principle Churches of Cairo and Alexandria and the Monasteries of Egypt, vol. 2, Cairo, 1942, p. 295, serial no. 648, call no. 648 Hist; G. GRAF, Catalogue de Manuscrits Arabes Chrétiens conservés au Caire (ST, 63), Città del Vaticano, 1939, p. 184, no. 479.

(20) ARMANIOS, Coptic Christianity in Ottoman Egypt, p. 48.

(21) Ibid., p. 46.

(22) S. Lane PoOle, A History of Egypt in the Middle Ages, New York, 1901, p. 344.

(23) LABIB, “John XIII," pp. 1346-1347. 


\section{THE TEXTS}

From the Tarh Batos, we are provided the following information:

The Tarh Adam does not provide any biographical information but simply words of praises.

The doxology Batos is copied from the doxology of Saint Menas.

The Arabic text is rich in information, and provides us with the following information:

The author of the psalis is Nicodemus. This author lived in Cairo where he wrote psalis for all the commemorated saints in this city, including Michael the New; his body was buried in the Church of Ma'adi. ${ }^{24}$

As previously mentioned, Nicodemus used Coptic words while thinking in Arabic, hence with the title of Cyr and John the physicians, he used coфoc $=$ wise while physician in Coptic is crinl; the confusion comes with the Arabic word حكيم which has a double meaning (physician and wise).

\section{BIOGRAPHICAL DATA}

From the biographical data in the liturgical texts, we learn that Michael was a monk who wore the Skhêma ${ }^{25}$ and suffered martyrdom on Saturday $4^{\text {th }}$ of Abîb 1210 AM (1494 AD) at the third hour in Cairo. Following his martyrdom, a woman reported seeing a divine sign. His body was translated to the Church of 'Adawiya.

It seems that Michael the monk later converted to Islam, insinuated in the Tarh: "who came from those of the eleventh hour because of his good confession in front of the king and his principals and the leaders of his government in Egypt." He then repented and confessed his Christian faith before the king and all the notables of his kingdom (they could be the Qadis) and the rulers saying: "I choose to die by the same death as my fathers and my grandfathers."

(24) Y. N. YousSEF, "Recherches d'hymnographie copte: Nicodème et Sarkis," OCP, 64 (1998), pp. 383-402; IDEM, "Nicodème auteur des psalies," OCP, 60 (1994), pp. 625-633.

(25) For the skhêma cf. O. H. E. BuRMESTER, The Egyptian or Coptic Church: A Detailed Description of Her Liturgical Services, the Rites and Ceremonies Observed in the Administration of Her Sacraments (Textes et Documents, 13), Le Caire, 1967, pp. 189, 194-196; G. VIAUD, La liturgie des Coptes d'Égypte, Paris, 1978, p. 86. 


\section{TEXTS AND TRANSLATION}

Our texts commemorate Michael who suffered martyrdom on the $4^{\text {th }}$ Abîb in the year 1210 AM.

\section{Fol. 12v-13}

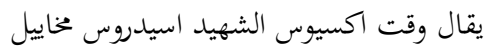

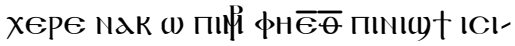
Аорос фнетас† мпечсшма $\bar{\epsilon} \bar{\theta}$

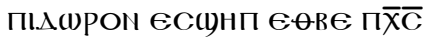

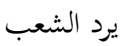

azıOC ICLAOPOC пाњ1

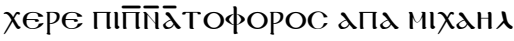
пирі фнетасымоү ехен †меөмн

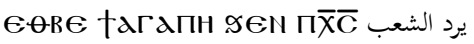
азIOC апа MІханג пाрі

хере NaK $\omega$ ПICTPa†גатHC ICLAOрос пирі фнетдсеркднрономім

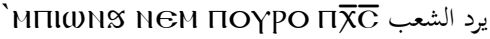

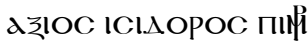

хере Naк () пाрі апа михана пимо-

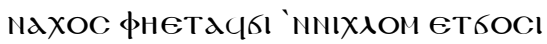

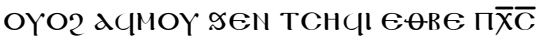
- يرد ال

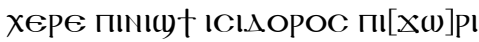

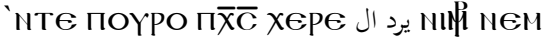
мІөмнІ []

хере Nak mixaна [] ]пмонахос фнетасер емп()д $\Theta \theta$ -

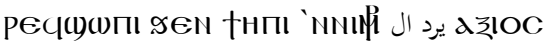

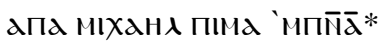

To be sung during the time of Axios (Worthy) for the Martyr Isidore and Michael the monk

Hail to you, O Martyr, the great saint who gave his holy body as an accepted gift for Christ

The people respond:

Worthy Isidore the martyr

Hail the Spirit-bearer Apa Michael, the Martyr who died for the truth because of (your) love in Christ.

The people respond: Worthy Apa Michael the martyr

Hail to you, O general Isidore, the martyr, who inherited life with Christ the King.

The people respond:

Worthy Isidore the martyr

Hail to you, O martyr, Apa Michael, the monk who received the sublime crown and died by the sword for Christ

Hail (to) the great Isidore, the mighty one of Christ the King, hail the just martyrs [ ]

Hail to you Michael [ ] the monk who became worthy to be numbered among the martyrs

People respond: Worthy Apa Michael the place of the Spirit 


\section{Fol. 14r-13r}

ابصالي ادام للشهيد ميخاييل الجديد

AITWв2 `мMOK ПаNOY† X(1) NHI $(1)$

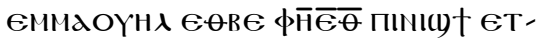
TAHOYT MIXAHA

BON MIBEN CETAIO MПIMONAXOC

оүо2 пाресбро мІханд пाні

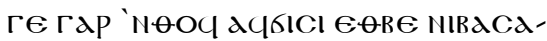

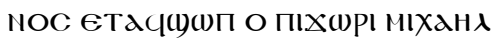
ПIMONAXOC

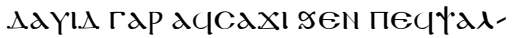

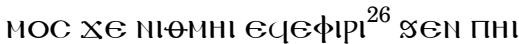

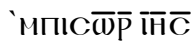

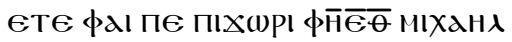

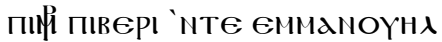

zeOW ema(y) 'nxe nekмет()En2нт () поҮро 'nте пшоY $\Pi \overline{\mathrm{X}} \overline{\mathrm{C}}$ пINגант

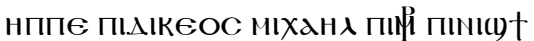

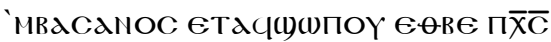

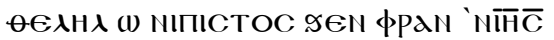

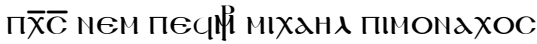

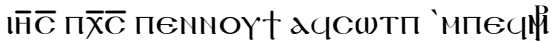

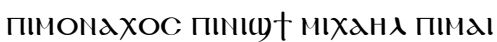
$\Pi \overline{\mathrm{X}} \overline{\mathrm{C}}$

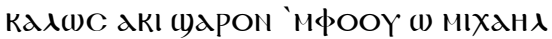

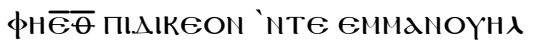

Psali Adam for the martyr Michael the New

I prayed to you, my God, forgive me, $\mathrm{O}$ Emmanuel for the (sake of the) great honoured saint Michael Everyone honour the monk and the victor Michael the martyr

For he became elevated because of the tortures that he endured, O mighty Michael the monk

For David said in his psalm: "the just (men) will flourish in the house of the Saviour Jesus ${ }^{27}$

Who is the mighty saint Michael, the new martyr of Emmanuel

Much is Your greatness, $\mathrm{O}$ king of glory, Christ the merciful

Behold, the just Michael, the martyr, (for) the great tortures that you endured for Christ

Rejoice, O faithful (ones), in the name of Jesus Christ and his martyr Michael the monk

Jesus Christ, our God, chose His martyr, the monk, the great $\mathrm{Mi}$ chael, the lover of Christ

Welcome ${ }^{28}$ to us today, O Michael the holy just (one) of Emmanuel

(26) Read eүєфıрı.

(27) Ps. 92:13.

(28) Lit. "You came well." 


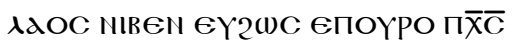

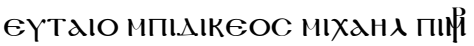

MOI HAN 'NTEK2IPHNH (1) ПХ(1)

'nnixponoc matal6o 'nnency)i єөвє палі

NaI nan C(NTEM EPON $\omega$ п $\bar{x} \overline{\mathrm{C}}$ OYO2

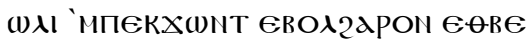

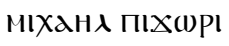

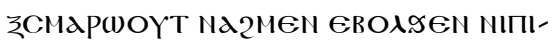
расмос єөве темаү нем фран мІхХнх пाрі

OYO2 XW NAN ANON EBOגSEN NEnanOMId OYO2 MaTAXPON (yd tCYNTENId

пеnnнв Xup 'nnenXaxi 'nte †*еккגнсіа Maөeвiо nем поY-

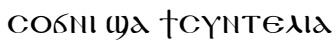

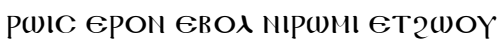

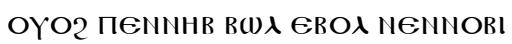
ETANAITOY

CMOY ENI ${ }^{29}$ 中IdPWOY ${ }^{30}$ neM NICIt nеM NIкарПос Єөвє NI†2O MIXанג пा1)

TEn†2O EөвE NIOYHB nEM NI-

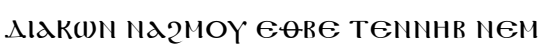
MІхан入 пाні
All the peoples praise Christ the King, honouring the just Michael the martyr

Grant us Your peace, till the end of the ages, heal our sicknesses for (the sake of) this martyr

Have mercy upon us, hearken us, $\mathrm{O}$ Christ and take away Your anger from us for the (sake of the) mighty Michael

Blessed are You, deliver us from temptations for (the sake of) Your mother and the name of Michael the martyr

And forgive us our transgression and confirm us till the end

Our Lord, disperse the enemies of the Church. Humble and counsel till the end

Guard us from evil men. Our Lord forgive us our sins.

Bless the (waters) of the river, the plants and the fruits for the (sake of the) prayers of Michael the martyr

We pray for the priests, the deacons deliver them, for (the sake of) our Lady and Michael the martyr.

(29) Add miог.

(30) Read 'mplapo. 


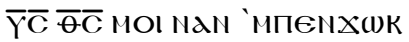

'nNIXPHCTIANOC EOBE TEKMAY NEM фPдN MІханд пाюі

中† ПIMAIPOMI MOI NaIN 'NOYMEPOC OYO2 'ntenXImI 'noYnal nem mini

xєрє †өєотокос Mapla $† \bar{\Pi} \bar{\alpha} \overline{\bar{p}}$ хере пाрі мІханג пाмондхос

TyXH Mamton nwOY gen

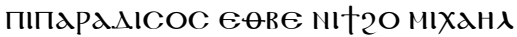
пाні

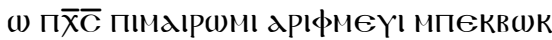
NIKOАHMOC ПIкEPMI АNOK Пє ПЄКвШК АHOK
Son of God, grant us our Christian perfection for (the sake of) Your mother and the name of Michael the martyr

God, the lover of mankind, grant us a share in order to find mercy with the martyr.

Hail to the Mother of God Mary the Virgin, hail to the martyr Michael the monk.

Souls repose them in the Paradise for the (sake of the) prayers of Michael the Martyr.

O Christ, the lover of mankind, remember Your servant Nicodemus the dust, I, myself, am Your servant

\section{Fol. 15v-14r}

ابصالي واطس للشهيد العظيم ميخاييل الجديد

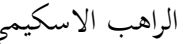

amoin ThPOY () namenpat:

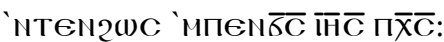

'ntentalo 'ntmacnoyt: nem mixaнג пแнा(y) пाрі

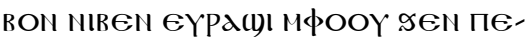
керфмеүі мпияі пимонахос пірес-

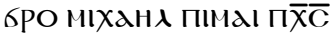

Ге гар асбыс емд(у) gen өMH†

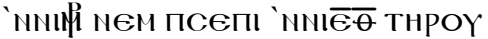

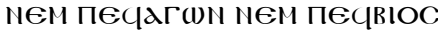

Psali Batos for the great martyr Michael the new, the monk (wearing) the Skêma

O come all my beloved in order to praise our Lord Jesus Christ, to honour the mother of God and Michael the great martyr.

Everyone rejoice, today is the day of commemorating the martyr monk the victor Michael, the lover of Christ

For you became elevated in martyrdom with all the rest of the saints because of (your) struggle and (your) life. 
AdYLA ПOYPO ПI2YMNOTOC ECX

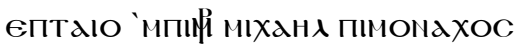
gen пाхшм 'мпесүадмос

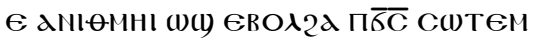

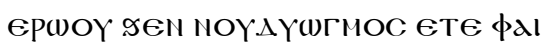
пе пाөєофорос мІханд пाрі

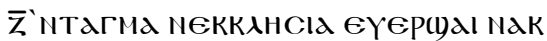

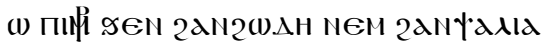

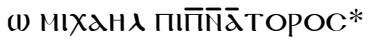

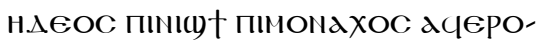

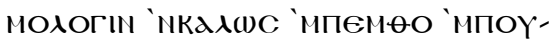
PO NEM NIEUNOC gEN фPAN 'мпєN $\overline{\mathrm{C}} \overline{\mathrm{i}} \overline{\mathrm{C}} \overline{\mathrm{C}} \Pi \overline{\mathrm{X}} \overline{\mathrm{C}}$

Ө)к те †Хом nем пітаIO $\omega$

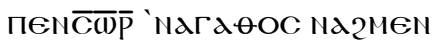

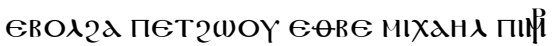

$\overline{\mathrm{iH}} \overline{\mathrm{C}} \Pi \overline{\mathrm{X}} \overline{\mathrm{C}}$ gen TENMH† 'MфоOY nem

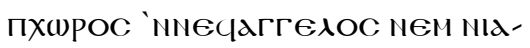
ПОстолос тнроү Єөвє мІханג Пџөхөфөाі

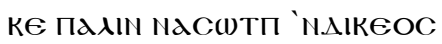

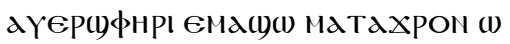
$\bar{Y} \overline{\mathrm{C}} \bar{\theta} \overline{\mathrm{C}}$ gen пекран еqMе2 'nшоY

ldOC 'nnIXPITIAHOC NEM NICAS

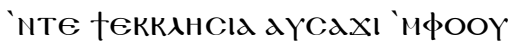

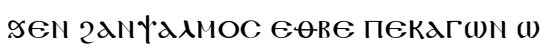
pd tcopla
David the king, the psalmist, said of the honour of the martyr Michael the monk in the book of his psalms:

The just have cried out and the Lord has heard them ${ }^{31}$ in their persecutions. That is the GodCarrier Michael the martyr.

Seven ranks of the Church rejoice with you, $\mathrm{O}$ martyr, with odes and psalis, O Michael the Spirit-bearer

The great monk pleasantly confessed well before the king and the nations in the name of our Lord Jesus Christ.

To You is the glory and honour, $\mathrm{O}$ our good Saviour deliver us from evil for (the sake of) Michael the martyr

Jesus Christ is in our midst today with the choir of His angels and all the Apostles for Michael

And also the chosen just ones are filled with admiration. Fortify us, O Son of God, in Your name that is full of glory

Christian people and doctors of the Church utter today with the psalms for your fight, $\mathrm{O}$ who has the wisdom

(31) Ps. 33 (34): 17-18. 


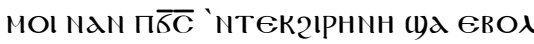
'nnixPOnOC OYO2 MaTdA6O

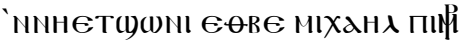

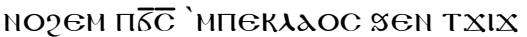

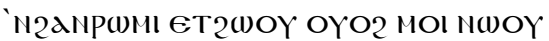
'nоүмерос nем міханג пाрецбро

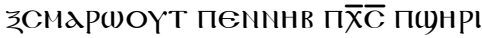

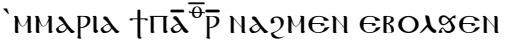
мипІрасмос єөвє мІханд пाрі

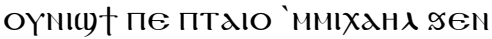

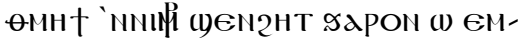

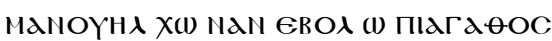

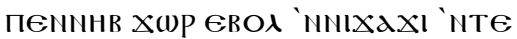

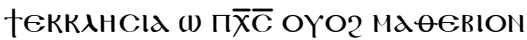

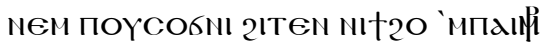

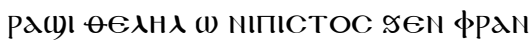
'мпеN $\bar{\sigma} \overline{\mathrm{C}} \overline{\mathrm{i}} \overline{\mathrm{C}} \boldsymbol{\Pi} \overline{\mathrm{X}} \overline{\mathrm{C}}$ neM TEqMaY

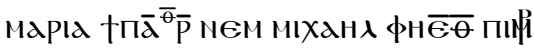

CMOY nIMUOY MфIAPWOY 32 neM NICI† nEM NIKגPпOC MapOYdIdI ката пєксмоү єөвє мІханд пाрі

TEN†2O EPOK ЄөBE NIOYHB NEM

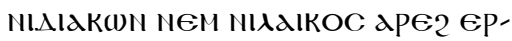

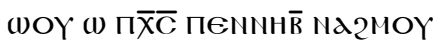
еволяеN nоYАІшгмос
Grant us, Lord, Your peace till the end of ages and heal our illnesses for (the sake of) Michael the martyr

Deliver, Lord, Your people from the hand of evil men and grant them a share with Michael the victor.

Blessed are you, our Lord Christ son of the Virgin Mary, deliver us from temptation for (the sake of) Michael the martyr

Great is the honour of Michael in the midst of the martyrs, have mercy upon us O Emmanuel, forgive us, O Good One

Our Lord disperse the enemies of the Church, O Church, humble the counsel through the prayers of this martyr.

Rejoice and be happy, O faithful ones in the name of our Lord Jesus Christ and His mother Mary the Virgin and saint Michael the martyr

Bless the waters of the river, the plants and the fruits, let them grow according to Your Blessing for Michael the martyr

We beseech You, the priests, deacons, and the laymen guard them, Christ, our Lord deliver them from persecution

(32) Read мфідро. 


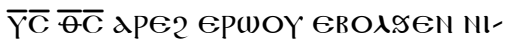

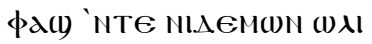

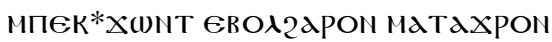
gen mINA2† ETCOYTWN

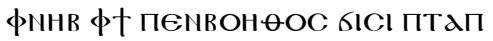
NMIXPHCTIANOC gen TXOM MП! $\overline{\mathrm{C}}^{\bar{P}} \overline{\mathrm{C}}$

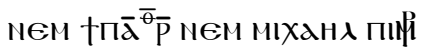

xepe †өєотокос mapla өmaY емMаноүнд Хере NaK пाні пігенпоєе $\bar{\epsilon} \bar{\theta}$ міханג

'YXH NIBEN MOI NaN NOYXBOB gEN

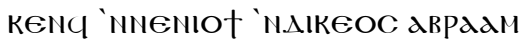
Ісдак Іакшв $\bar{\epsilon} \bar{\theta}$ єөвє мІханд пाрі

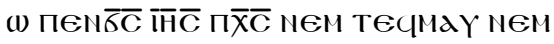
пєслі арІфмеүІ 'мпєквшк NHKOY.АHMOC gEN TEKMETOYPO NEM NIחICTOC
Son of God guard them from the snares of the devil, take away Your anger from us and fortify us in straight faith

Lord God, our helper, raise the horn of the Christians through the power of the cross, the Virgin and Michael the martyr.

Hail the God-bearer, Mary the mother of Emmanuel, hail to you brave martyr Saint Michael

All souls grant us rest in the bosom of the just ones, the fathers Abraham, Isaac and Jacob, and for (the sake of) the martyr $\mathrm{Mi}$ chael

O our Lord Jesus Christ with His mother and His martyr remember Your servant Nicodemus in Your kingdom with the faithful ones.

\section{Fol. 16r-v}

ذكصولوجية ادام تقال قبل الطرح الادام

Ө)OY THPOY MфOOY $\mathrm{\omega}$ mixphCTIAnOC 2Ind 'ntentalo мІханл пाюі

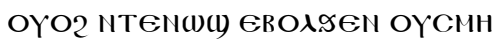

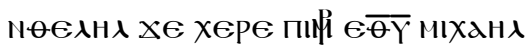

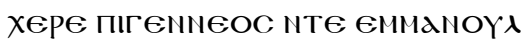
хере пाдөлофорос 'мін міханд

хере фнетаст 'мпессемд єПххршм єөве тєСаГаПн ммн sen фPAn $\in \Pi \overline{\mathbf{X}} \overline{\mathrm{C}}$
Doxology Adam to be said before the Tarh Adam

Assemble all today $\mathrm{O}$ Christians in order to praise Michael the martyr

And to sing in a joyful voice: "Hail to the holy martyr Michael

Hail to the courageous one of Emmanuel, Hail to the fighter martyr Michael

Hail to him who gave his body to the fire for his true love in the name of Christ 


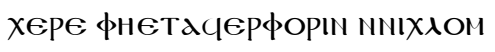

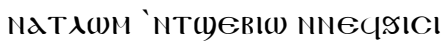

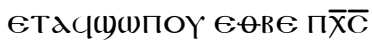

херє пाмонахос херє ПІдскүтнС Хере пाрі мІханג пाдөגүтнс

Херє ПІрєЧбрО єөвє ПєЧдГШн

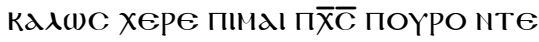
NIOYPWOY

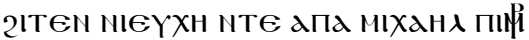
$\Pi \overline{\bar{\alpha}} \overline{\mathrm{C}}$
Hail to him who wore the imperishable crown in reward of his suffering that he received for Christ's sake

Hail to the monk, hail to the ascetic (one), hail to the martyr Michael the struggler

Hail to the fighter for his good fight. Hail to the lover of Christ the King of kings

Through the prayers of Michael the martyr, Lord

\section{Fol. 16r}

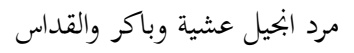

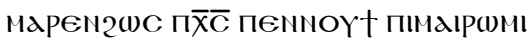

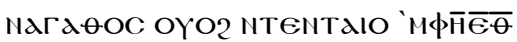
пाмну十 дпа миханд пाрі
Response for the Gospel of the Vespers, the Matins and the Eucharist:

Let us praise Christ our God the good lover of humankind and let us honour the great saint Apa Michael the Martyr

\section{Fol. 17r-16v}

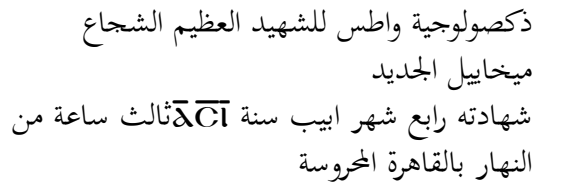

Doxology Batos to the great brave martyr, Michael the new, and the day of his martyrdom on the fourth day of the month Abib in the year $1210^{33}$ in the third hour of the day in the protected (city of) Cairo

(33) AD 1494. 
Є()П ОN NTE NIPФMI ХEM2HOY

'мпाкосмос тнру 'nтея†осІ

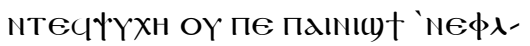
HOY

миханд пाрі ассотем 'нса †смн mNOY十 асх(1) мПІкосмос тнр4 ЕүсоП нем печшоү Еөме2 мпவ $\theta 0 C$

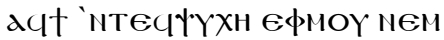

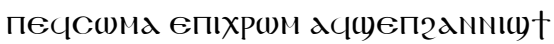

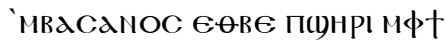
eTONg

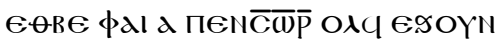
EтеपMEтоYPO dat nWOY NNIdгаөON NHETE MПE Bdd naY EPWOY aү† nixлом еволяеn тфе Exen тафе 'ммІханג* пाмонохос пाрі חI.AldK(1) nTE $\Pi \overline{\mathbf{X}} \overline{\mathrm{C}}$

'nt(yeria) 'nmiracanoc

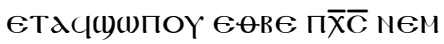

т2евсе 'nnimonaxос nем пाсхіма 'ндггелікон

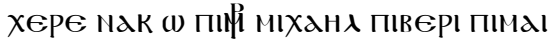
$\Pi \bar{x} \bar{c}$ фнетдсфон мпєсснос єөвє фPAN Nī̄ $\overline{\mathrm{C}} \Pi \overline{\mathrm{X}} \overline{\mathrm{C}}$

Тшвг підөлофорос 'мюі міханд

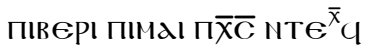

If therefore a man should gain the whole world and forfeit his soul;34 what is this great vanity

Michael the martyr obeyed the Divine voice and rejected the whole world together with its glory that is full of passions

He gave his soul over to death and his body to the fire. He endured great tortures for the sake of the Son of the living God.

Therefore our Saviour lifted him up in His kingdom and gave good things that no eyes can see ${ }^{35}$

Heavenly crowns are placed on the head of Michael, the martyr, monk the deacon of Christ

in place of tortures that he endured for Christ and the garment of the monks and the angelic skhema.

Hail to you O Martyr Michael the new the lover of Christ who shed blood for the name of Jesus Christ Pray ... the fighter martyr Michael the New the lover of Christ in order... 


\section{Fol. 20v-17r}

طرح ادام للشهيد الجليل مخاييل الجحيد الراهب

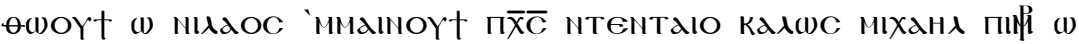

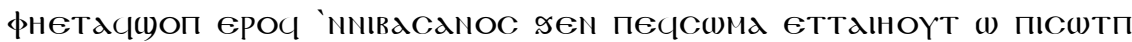

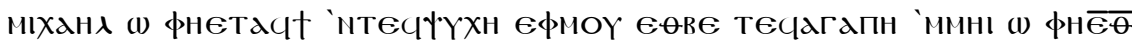

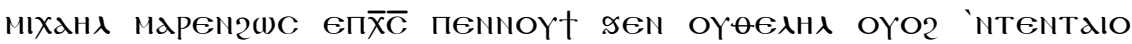

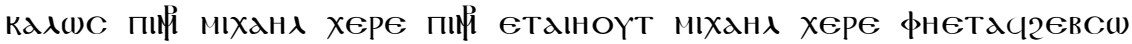

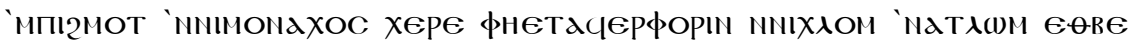

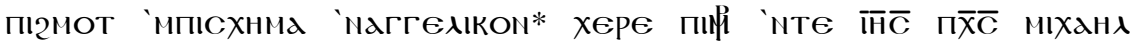

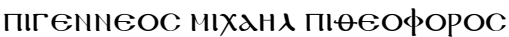

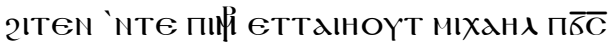

ويخلصنا من يد الاعدا المناصبين لنا ويبدد مشورة المعاندين لبيعته وشعبه ويجمع شمل اولاد البيعة بالالفة والمحبة الروحانية ويبعد عنهم انشقاق وكل الموامرات الردية وينشي اولادها النشاة الصالحة المرضية بشفاعة الست السيدة العذرى الطاهرة مارة مريم البتول الزكية وساير مصاف الطقوس النورانية وكل مصاف الشهدا والقديسين فلنصرخ بصوت الفرح قايلين

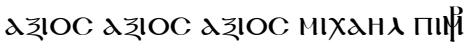

dzlOC $M^{x} 1$ חIMONaXOC

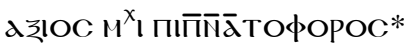

فلنمدح هذا الشهيد العظيم بصوت الفرح والتهليل قايلين السلام لك ايها اللابس الجهاد الشهادي ميخاييل الجحديد المتوشح بالاشكال الملايكية الذي فار بالخيرات السرمدية السلام لك ايها الشهيد حبيب المسيح وصفيه المختار الذي استحق من الرب اكاليل نورانية غير مضمحلة السلام لشهيد المسيح ميخاييل الذي ابذل جسده للعذاب والحرق النار من اجل حرارة الروح الساكنة فيه وكثرة تشوقه الى ملكوت السموات السلام لشهيد المسيح ميخاييل الذي خرجت صفوف مراتب الشهدا للقايه وسمع الصوت الالهي ادخل الى لى فرح سيدك السلام لك ايها الشهيد العظيم ميخاييل الجلديد الذي صار جسده مينا خلاص لكل الاتين اليه وخلاصا للذين في الشدايد وشفا لذوي الاسقام السلام للمكان الذي وضع فيه جسدك الطاهر وفرحا لاولاد البيعة اسال الرب من اجلنا لكي يرحمنا كعظيم رحمته وينعم علينا بالاعتراف باسمه الى النفس الاخير

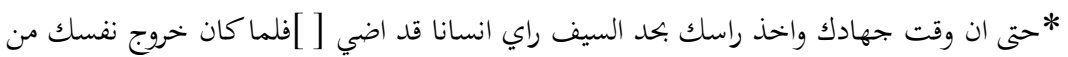
الجسد رالها كمثل درة جميلة المنظر وكمثل طاير اخضر نورانيا وان شابة من الخارجين رات راسك عند قطعها من الجمسد صرخت قايله انا نصراين مومنا بالمسيح حتي دهنت وكلمن سمعها وملا ضجروا اوليا الامور من التهديد والتخويفات تكلموا فيما بينهم على قطع راسك فقطعت راسك المقدسة في الساعة الثالثة من يوم السبت المبارك الرابع من شهر ابيب ولما اخذت راسك المقدسة توامروا اوليا الامور الذي حضروا وقت قطع 
راسك فعند ذلك سخطوا جسدك المملو من نعمة روح القدس الى حيث مكان يحرقوا فيه جسدك وملا ارموك

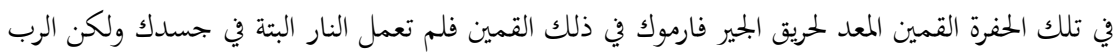
يحفظ جميع اعظا الشهدا وواحدة منها لا تتلف وان كثيرة من فيه المخافة من الرب سبحانة واخذ عظامه * ترجع الى خلفك وانا انت ايها الحبيب فلم يهدلك ترهيباتم ولا تخويفاتم لكن كان عقلك مرتفعا الى العلو مستنظرا سعادة ابدية ومملكة سمايية ولم يخاف من عذاب الملوك ولكن كمثل القول الالهي لا تخافوا ممن يقتل الجسد واعترفت جهرا باسم المسيح القايل من فاه الالهي من اعترف بي قدام الناس اعترفت انا به قدام ابي في السموات سالت الملكوت الابدية فانعم الرب عليك عوضا عن افضل الامور العالمية طلبت الاختلاط بالزمرة الملايكية والمراتب النورانية قرعت فتحت لك ابواب الملكوت وسمعت الصوت الفرح القايل ادخل المى فرح سيدك لقد فرحت كورة مصر بجهادك الحسن ايها القابض عليه نعمة روح قدسه وشملته القوة الالهية حتى صار معاندا ومضاددا لكل المترددين اليه من اكابر الدولة بالمملكة المحروسة المصرية حتي صاروا داهشين ومتعجبين من عظم صبرك وقوة شجاعتك يا حبيب المسيح وصاروا ذو قلبين ولم يستطيعوا ان يتكلموا بفضايلك خشية ان يكون عاراً وخزيا لمم* ولحريق النار واخر من اجل لبس ثياب الخلاص الذي كانت سببا لخلاص الابا انطونيوس ومقاريوس وبخوميوس وابو شنوده واولادهم لباس الصليب ولاسيما يزيادة لباس

الاسكيم الطاهر الشكل الملايكي وخوذة الخلاص الذي هو القلنسوة لباس الثلاثة فتية القديسين حقا استحقيت درجة عالية وكمل عليك القول المنصوص في الابجيل الشريف القايل لا تخافوا ممن يقتل الجسد ولا يستطيع ان يقتل النفس خافوا ممن يقدر ان يهلك النفس والجسد جميعا في جهنم ومن اعترف بي قدام الناس اعترفت انا به قدام ابي الذي في السموات ويقول ايضا سلوا تعطوا اطلبوا بتحدوا اقرعوا يفتح لكم حقا تقدمت بنشاط وشجاعة وقوة الالهية وتقدمت امام الملك وعظما المملكة يمضي واعترفت جهرا باسم المسيح ولم يهدلك سطوة الملك ولا عظما مملكته ولكن النعمة الالهيه اشتعلت داخلك وتكلمت معهم صارخا قايلا انني اموت الذي ماتوا به اباي واجدادي وانا مستعد ان اموت به وللوقت خرج امرا من الملك بالامهال 36 الهيه لعل ان** مديح من اجل التذكار الكريم الذي للشهيد المكرم حبيب الله العظيم الراهب الناسك المتوشح بالاشكال الملايكية بالاسكيم المقدس المدعو لاجل الشهادة ميخاييل الجديد الرب يجعل لنا معه نصيبا وميراثا وثبتا على الاعتراف باسمه الى النفس الاخير ويخلصنا من ساير العوارض والحوادث الزمنية وينعم لها بالرحمة وغفران الخطايا امين حقا اشرق لنا اليوم تذكارك المكرم والشهيد المبارك ميخاييل محب المسيح يا من قبل اليه الاتعاب في جسده المكرم واهرق دمه من اجل اسم يسوع المسيح يا داوود المرتل قم تعال وسطنا اليوم لتقول كرامة [ الشهيد مخاييل الراهب قال كثيرة هي احزان الصديقين ومن جميعها يخلصهم الرب الرب يحفظ جميع عظامهم وواحدة

(36) Read بالألمام. 


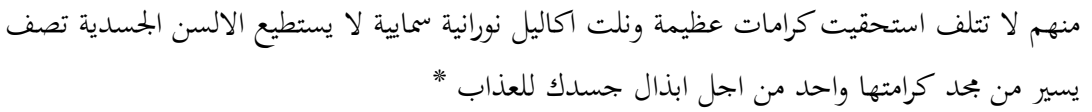

Tarh Adam for the honoured martyr and monk Michael the New. Let us assemble O God-loving people in order to give honour to Michael the martyr who endured tortures in his honoured body, O chosen Michael who gave his soul to death for the sake of true love, O saint Michael! Let us praise Christ our God with joy and rightly honour the martyr Michael. Hail to the honoured martyr Michael, hail to him who wore the grace of the monks. Hail to him who bears the imperishable crown for the grace of the angelic skêma. Hail to the martyr of Jesus Christ, Michael, the brave Michael the God-carrier. Through ...of the honoured martyr, Michael, Lord deliver us from the hands of the enemies opposing us and disperse the counsel of those resistant to His church and His people. And let Him unite the children of the Church in harmony and spiritual love and let Him put away schism, and all conspiracy. Let Him raise her (the Church's) children with good pleasant education. Through the intercessions of the the pure Virgin, the Lady Mary the pure, chaste one, and all the ranks of light, and the ranks of the martyrs and saints. Let us sing with joy saying:

Worthy, Worthy, Worthy, Michael the martyr

Worthy, Michael the monk

Worthy, Michael the Spirit-bearer.

Let us praise this great martyr with joyful and happy voices saying: "Hail to you O fighter and Martyr Michael the New, who wears the angelic skhêma and gains the Eternal rewards. Hail to you, Obeloved of Christ, the chosen friend who became worthy of the imperishable crowns. Hail to the martyr of Christ Michael who offered his body to endure tortures and be consumed by fire because of the fervency of the Spirit dwelling in him and his great desire for the kingdom of Heaven. Hail to the martyr of Christ, Michael whom the ranks of the martyrs came to greet and he heard the divine voice saying: "enter into the joy of your Lord." 37 Hail to you, O great martyr Michael the New, whose body became a harbour of salvation to all who are coming to him and a deliverance from distresses and a healing for the sick. Hail to the place where your pure body rests that has become a joy for the children of the Church. Pray to the Lord on our behalf so that He has mercy upon us according to His great mercy

Mt 25:21. 
and grant us the confession of His name to the last breath. *So that during your struggle and severing your head with the edge of the sword he ${ }^{38}$ saw a man of light [ ] at the time your soul was released from your body. He saw it like a beautiful pearl and like a green bird. A young lady, when she saw your head severed, cried out saying: "I am Christian, believing in Christ and she anointed." 39 All who heard her from the rulers were annoyed from threatening and fearing. They agreed amongst themselves to sever your head. Your head was severed in the third hour on the blessed day of Saturday on the fourth of Abib. The rulers were present during your martyrdom. They were enraged against your being that was full of the grace of the Holy Spirit and so ordered your body to be burned. They threw you in the lime-kiln but the fire did not consume your body, for the Lord will guard the members of the martyrs and not one of them will perish. ${ }^{40}$

Some God-fearing people - let God be exalted - took the bones and you did not look back.

And you, $\mathrm{O}$ beloved, did not fear their threats and terror. But your mind was elevated to the highest, looking forward to the eternal joy and the Heavenly Kingdom. He did not fear the tortures of the kings, for the divine words state: "Do not fear those who kill the body." 41 You confess openly the name of Christ who said by His divine mouth: "Whosoever therefore shall confess Me before men, him will I confess also before My father who is in heaven." 42 You sought the Eternal Kingdom and so the Lord rewarded you with good things to be associated with the angelic ranks and the choirs of light. You knocked and to you ${ }^{43}$ the gates of the Kingdom were opened. You heard the happy voice saying: "enter into the joy of thy Lord." 44

(38) These phrases and psalis keep changing between the first person and the second person. We prefer to keep it as close to the original script as possible.

(39) It seems that something is missed in this sentence such as she anointed "her head with his blood"?

(40) Ps. 33(34):19-20.

(41) Mt. 10:28.

(42) Mt 10:32.

(43) Mt 7:7.

(44) Mt 25:21. 
The country of Egypt rejoiced in your good fight, that through the grace of His Holy Spirit and the divine power you were able to oppose those great ones of the state of the protected kingdom of Egypt.

They were amazed by your patience and the might of your courage, $\mathrm{O}$ beloved one of Christ. They were shaken and unable to utter your virtues so that shame and confusion fell on them... ${ }^{45}$

[you received a crown] for being consumed by fire and one for wearing the garment of salvation, which is that received by Abba Antony, Abba Macarius, Abba Pachomius, Abba Shenoute and their children the Cross-bearers. Moreover, by wearing the pure skhêma, the angelic form, the helmet of salvation, ${ }^{46}$ which is the cuculle worn by the holy three young men, truly you became worthy of elevation. The word of the Gospel was accomplished in you: "fear not those who kill the body, but are not able to kill the soul but rather fear Him who is able to destroy both soul and body in hell." 47

"Whosoever therefore shall confess Me before men, him will I confess also before My father who is in heaven." 48 He said also: "Ask, and it shall be given you; seek, and you shall find; knock, and it shall be opened unto you." 49 Truly you advanced with zeal and courage and divine power. You advanced in front of the king and the great ones of the kingdom and you confessed openly the name of Christ. You did not fear the authority of the king and the greatness of his kingdom, because the divine grace was fervent in you. You cried out with them saying: "I will die by the death of my fathers and forefathers. I am ready to die by it!" At once the order of the king was issued.

We praise you in your precious commemoration O honoured martyr, the beloved of God, the ascetic monk who wore the angelic forms of the holy skhêma, who was called for martyrdom, Michael the New. May the Lord grant us a share and inheritance and confirm us in our faith, in order to confess His name to the last breath and deliver us from all obstacles and temporal difficulties, and grant us mercy and the forgiveness of our sins. Amen.

(45) It seems some text is missing here.

(46) Eph 6:17.

(47) Mt 10:28.

(48) Mt 10:32.

(49) Mt 7:7. 
Truly, your honoured commemoration shines on us today, O blessed martyr Michael the lover of Christ, who received the passions in his honoured body, who shed his blood in the name of Jesus Christ. O David the psalmist come in our midst today in order to tell us of the honour of the martyr Michael the monk, saying: "Many are the afflictions of the just, the Lord will deliver them from them all. The Lord will guard their bones: not one of them will perish." 50 You became worthy of great honour and you received the luminous heavenly crowns that no fleshly tongues are able to describe even a fraction of its honour. A man offered his body to be tortured.

\section{Fol. 21r-20v}

طرح واطس للشهيد الجليل ميخاييل الراهب الناسك

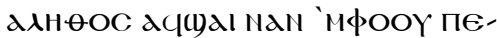

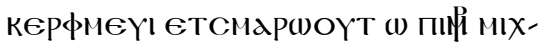

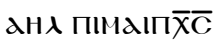

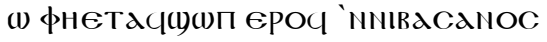
gen пеपCWMd ETTdIHOYT OYO2

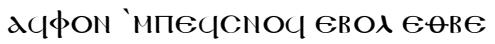
фPAN 'Nī̄ $\overline{\mathrm{C}} \Pi \overline{\mathrm{X}} \overline{\mathrm{C}}$

(1) AdY П.А ПI2YMNOTOC TWNK גMOY

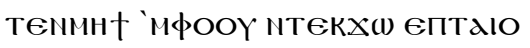

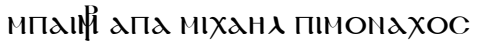

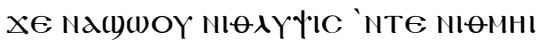

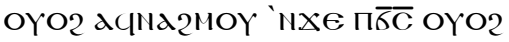

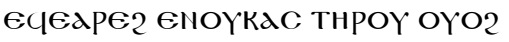

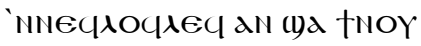

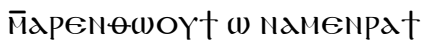

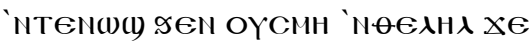

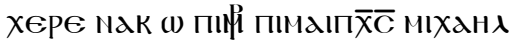

Tarh Batos for the honoured martyr Michael the ascetic monk

Your blessed commemoration truly rises to us today, $\mathrm{O}$ martyr Michael, the lover of Christ

$\mathrm{O}$ he who received the tortures in his honoured body and shed his blood for the sake of the name of Jesus Christ

O David, the psalmist, arise and come in our midst today in order to utter the honour of this martyr Apa Michael the monk.

Many are the afflictions of the just, and the Lord will deliver them from them all. He will guard all their bones: not one of them will perish. ${ }^{51}$

Let us assemble, $\mathrm{O}$ my beloved, in order to sing with a joyful voice: "Hail to you, O martyr, the lover of Christ Michael
(50) Ps. 33(34):19-20.
(51) Ps. 33(34):19-20. 
хере пак $\omega$ пाгенnеос прі $\overline{\epsilon \theta}$

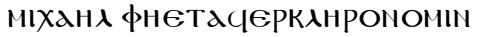
MПICNS NEM NI.AIKEOC

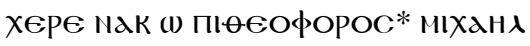

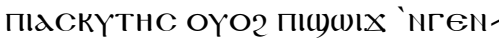
neOC фнетасер(y)al neM nipi

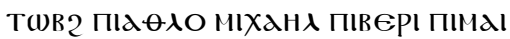
$\Pi \overline{\mathbf{x}} \overline{\mathrm{C}}$ nTEप
Hail to you O brave holy Martyr Michael who inherited life with the just (ones)

Hail to you, O bearer of God, Michael the ascetic one and the brave courageous one who rejoices with the martyrs

Pray... O fighter Michael the new, the lover of Christ that

\section{Fol. 23v}

مرد الانجيل للشهيد ميخاييل الجلديد $\quad$ Response to the Gospel for the martyr Michael the New:

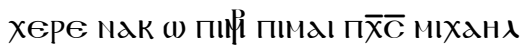
фнетдсфон мпреспос євод єөве фPAN NEMMANOYHA

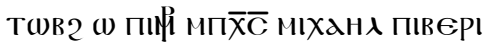
mimondXOC nTEG
Hail to you O Martyr, the lover of Christ, Michael, who shed his blood for the sake of Emmanuel

Pray... O martyr of Christ, Michael the New and monk, in order...

\section{Fol. 26v-24r}

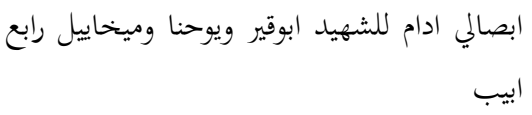

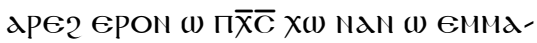

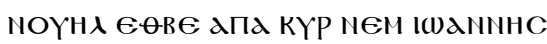

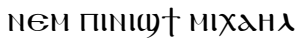

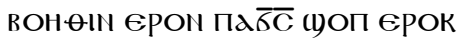

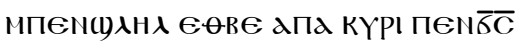

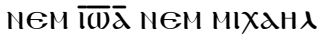

ге гар 'нөшOY dYбlCl dПג KYPl

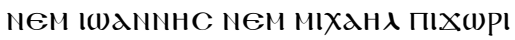
gen өмн† 'мпाрі
Psali Adam for the martyr Apa Cyri, John and Michael for the $4^{\text {th }} \mathrm{Abîb}$

Preserve us $\mathrm{O}$ Christ, forgive us, Emmanuel for (the sake of) Apa Cyri and John and the great Michael

Help us, O Lord, receive unto You, our prayer for (the sake of) Apa Cyri our lord, and John and Michael

For they are elevated, Apa Cyri and John and Michael the Great, in the midst of the martyrs 
AdYL dMOY TENMH† 'MфOOY $\omega$

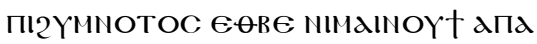
KYPI NEM IWANMHC

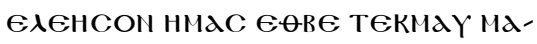

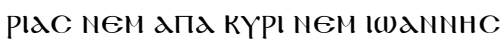
NEM MІХднג NINі

zeOly 'NnIBdCANOC ETAYC)ПOY

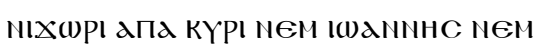
мІхגнд пाверІ

нППЕ дNON NIחICTOC TENEP(y) 'MфOOY gen meyd 'nnalpi 'nte поҮро 'nте пшоҮ

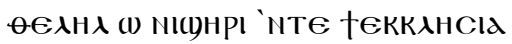

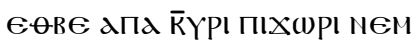

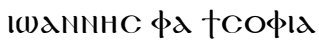

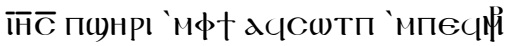

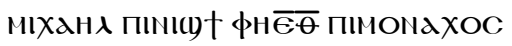

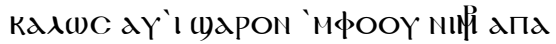

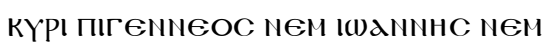
MIXAHג

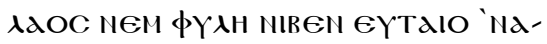

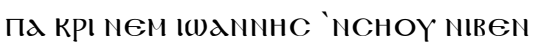

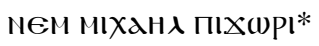

MOI NAN 'NTEK2IPHNH EөBE NEK-

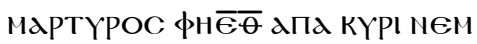
IWANNHC NICOQOC

NIET2OX2EX Na2MOY EвOג9EN

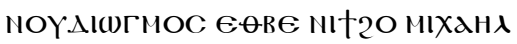
пIMONaxOC
David the psalmist, come in our midst for the (sake of) Apa Cyri and John who love God.

Have mercy upon us for (the sake of) Your Mother Mary and Apa Cyri, John and Michael the martyrs

Numerous are the tortures that they received, the mighty Apa Cyri and John and Michael the New

Behold, we the faithful ones, rejoice today on the feast of these martyrs of the King of glory

Rejoice, O children of the Church, for Apa Cyri the mighty and John who has wisdom

Jesus the Son of God, chose His martyr Michael, the great saint and monk

Welcome to you today martyrs Apa Cyri the brave, John and Michael

All people and nations honour Apa Cyri and John at all times and Michael the Mighty.*

Grant us Your peace, for (the sake of) Your martyrs, Apa Cyri and John the Wise

Those who are afflicted, delivered them from persecution for the (sake of the) prayers of $\mathrm{Mi}$ chael the monk 


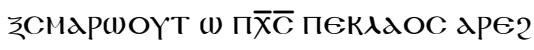

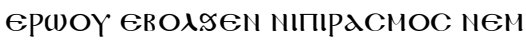
NIPEMI ET2WOY

OYO2 Xup `nnIXdXI 'nTe †еккגнсіа sемяомоү nем поYcosni (yd tCYntenia

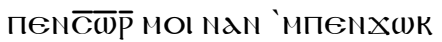
'nXPHCTIANOC OYO2 MaTAXPON Wd пхшк 'nnIxPOnOC

P(DIC EPON €өвє дПа күPI nем

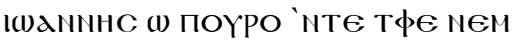
мІханх пाюі

CMOY ENIфIAPWOY 52 NEM NICI† nEM NIKגрпOC єөве NI†2O dПג KYPI NEM I(DANHHC

TENTWв2 Єөвє NIOYнв NEM NIAldK(NNOC Na2MOY $(1) \Pi \bar{X} \overline{\mathrm{C}}$ ПENNHB sen Txix `мпі.дүраnnoc*

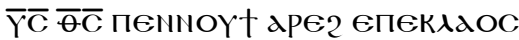

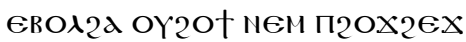
МП[ІРd]CMOC

中† бІСІ ПТАП 'NMIXPHCTIANOC

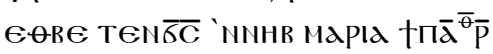

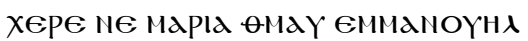
хере †пандгіа нем пाєм NIEZEKIH入

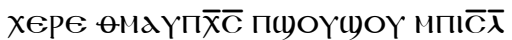
хере апа күрі nем Ішаnnнс хере

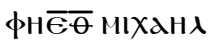

Blessed are You, O Christ, preserve Your people from temptation and evil men

And disperse the enemies of the Church, crush them and their counsel forever

Our Saviour, grant us our Christian perfection and fortify us till the end of ages

Keep us for (the sake of) Apa Cyri and John, O King of Heaven and Michael the martyr

Bless the (waters) of the river, the plants and the fruits, for the (sake of the) prayers of Apa Cyri and John.

We beseech You to deliver the priests and the deacons, $\mathrm{O}$ Christ our Lord from the hand of the Tyrant*

Son of God, our God, preserve Your people from fear and passion of temptations

God, raise the horn of the Christians for (the sake of the) Lady Mary the Virgin

Hail to you Mary the mother of Emmanuel, hail to the all holy and the knowledge of Ezekiel

Hail to the mother of Christ, the pride of Israel, hail to Apa Cyri and John, hail saint Michael

(52) Read nimivoY `мфiдpo. 
YrXh mamton nwoY gen піпараль- Repose souls in Paradise together COC nем текмаY †оүр() nем NIAKeOC

with Your mother the queen and just one.

WOYN2HT АРІфMеүІ 'МПЕКвШК NIкоYAHMOC OYO2 Xw maq 'nmeqmoви нем псепі 'мпппетос*

Be patient and remember Your servant Nicodemus and forgive him his sins together with the rest of the faithful.

Fol. 27r-

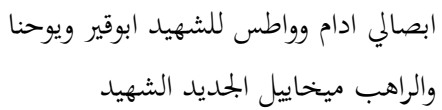

apietin (1) namenpat 'ntenzwC

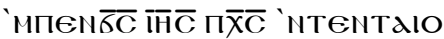
'n†масnоү† mapla †бромп єөNнCOC

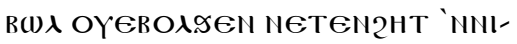

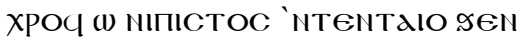
OYө(1) N2HT аПג KYPI NEM IDANIHC NICOфOC

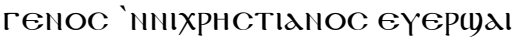
'MфOOY gen OY $\theta \in \lambda H \lambda$ gen ח(1)dI

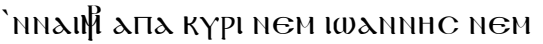
MIXHAd

AdYLA дMOY TENMH† MфOOY

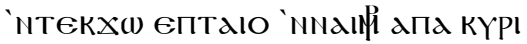

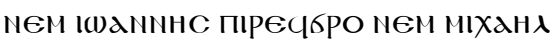

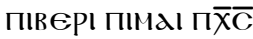

EגeHCON HMAC O $\bar{\theta} \overline{\mathrm{C}}$ 2ITEN NI-

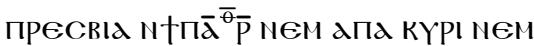
IDANIHC NICOфOC NEM MIXAHג пIMOHdXOC*
Psali Adam and Batos for the martyr Apa Cyri and John and the monk Michael the New martyr

Ask, O my beloved, in order to praise our Lord Jesus Christ and to honour the mother of God, Mary the beautiful dove

Remove guile from your hearts, O faithful ones, in order to honour Apa Cyri and John the wise with a content heart

Christian nations rejoiced today at the feast of these martyrs, Apa Cyri and John and Michael

David come in our midst today in order to sing the honour of these martyrs Apa Cyri and John the Victorious and Michael the New, the lover of Christ

Have mercy upon us O God, through the intercession of the Virgin and Apa Cyri and John the wise and Michael the monk 


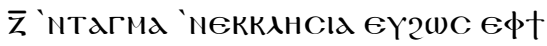
емmanоүнд еүерхшреүIN gen

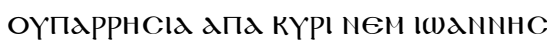
NEM MIXAHג

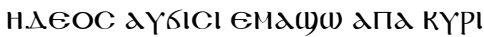

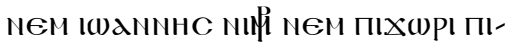

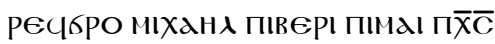

Ө)к TE †ХОм nем ПIтдIO $\omega$ пеN $\overline{\mathrm{C}} \overline{\mathrm{P}} \overline{\mathrm{P}}$ 'NaГd

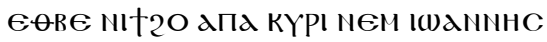
NIIPI

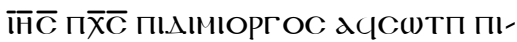

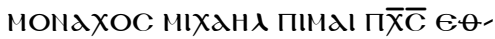
ресу⿴囗卄一 нас 'nоүні

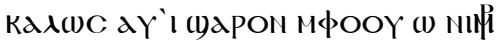

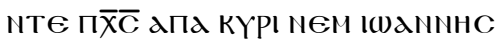

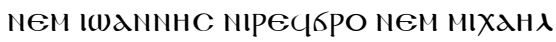
пIMONAXOC

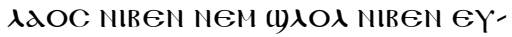

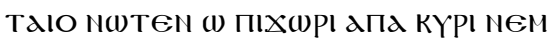

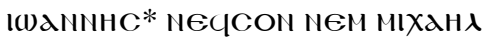
ПІөмнІ пІвєрІ

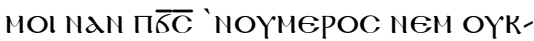

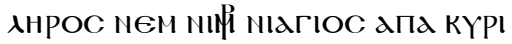

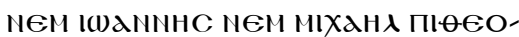
фOPOC

nal Nan OYO2 CWTEM EPON NA2MEN

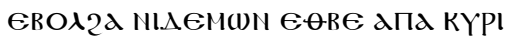

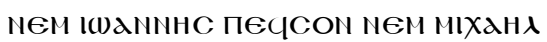
Пı.АІкеON

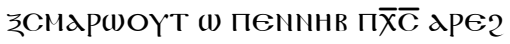
ePOn gen NIחірдсMOC 2ITEN NI†2O

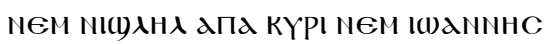

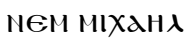

Seven ranks of the Church praise God Emmanuel, and openly praising Apa Cyri, John and Michael

Wonderfully are they elevated, Apa Cyri and John the martyrs, and the mighty, victorious $\mathrm{Mi}$ chael the New, the lover of Christ.

To you are the power and the honour, O our Good Saviour. Forgive us for the sake of Apa Cyri and John the martyrs,

Jesus Christ the Creator chose the monk Michael the lover of Christ in order to make him a martyr

Welcome today, $\mathrm{O}$ martyrs of Christ, Apa Cyri and John the victorious and Michael the monk

All people honour you, $\mathrm{O}$ mighty Apa Cyri and John his brother and Michael the just, the new.

Grant us, Lord, a share and inheritance with the martyrs, saints Apa Cyri and John and Michael the God-bearer

Have mercy upon us, listen to us, deliver us from the devils for (the sake of) Apa Cyri and John his brother and Michael the just.

Blessed are you, our Lord, Christ, preserve us during temptations through the intercessions and prayers of Apa Cyri, John and Michael 
OYO2 MOI nan 'n†2YחOMONH gen

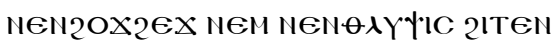

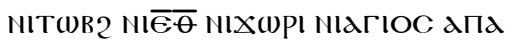
KYPI NEM IOANMHC

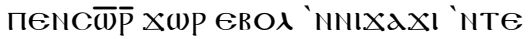
†єккגнсіа () еммамоүнд єөвє

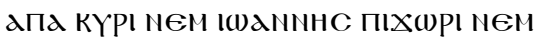
пгеNNEOC MIXдH $\lambda^{*}$

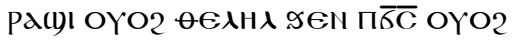
дxос gen oү $\theta \epsilon \lambda н \lambda$ xє херє

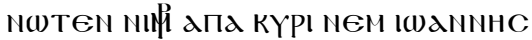
nEM MIXAHג

CMOY E NIMWOY MфIAPWOY nEM NICI† neM NIKapпOC MapoYalal $\omega$ поүро 'nте пшоү єөве дПג күрI nем ІшаNnне NipeqбPO

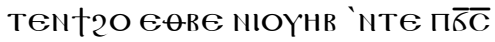
NEM NIAIAKWN NEM NIגdIKOC

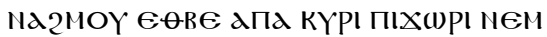

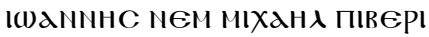

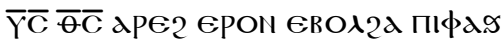

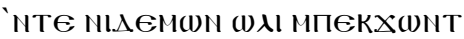

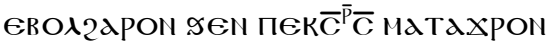

фNHB NMIXPHCTIANOC 2ITEN NI†2O n†өєотокос nеM dПג күPI neM

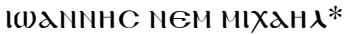

Xepe ne $\omega$ †ா $\bar{\alpha}^{\bar{\theta}} \bar{p}$ Mapla ӨMaY neM-

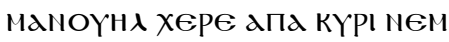
I(1)dNMHC NICOфOC nem пINIC† TAIHOYT MIXAHג
And grant us patience in our sufferings and distresses through the prayers of the holy, mighty saints Apa Cyri and John

Our Saviour, disperse the enemies of the Church, O Emmanuel, for (the sake of) Apa Cyri and John the Mighty and the brave Michael

Rejoice and be happy in the Lord and say in happiness: Hail to you O martyrs Apa Cyri, John and Michael

Bless the waters of the river, the plants and the fruits, let them grow, O King of Glory for (the sake of) Apa Cyri and John the Victorious

We beseech You for the priests of the Lord, the deacons and the laymen, deliver them for (the sake of) Apa Cyri the Mighty, John and Michael the New

Son of God, preserve us from the snare of the devils, take away Your anger from us. Fortify us with Your Cross

Lord God, our Helper, raise the horn of the Christians through the prayers of the God-bearer (Youhanna? - is this 'God-bearer' St Mary?) and Apa Cyri, John and Michael

Hail to you, O Virgin Mary, the mother of Emmanuel, Hail to Apa Cyri and John the wise and the great honoured Michael 
TYXH NIBEN MOI NWOY HOYXвOB HEM оүмерос Nем †п $\bar{\alpha} \overline{\mathrm{p}} \overline{\mathrm{P}}$ нем апа күPI

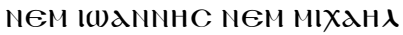

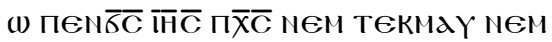
некі дрІфмеүІ мпеквшк нІкоүАHMOC нем псеП 'mnхрнстіанос
Grant all souls repose and a share with the Virgin, and Apa Cyri, John and Michael

O our Lord Jesus Christ and Your Mother with the martyrs, remember your servant Nicodemus together with the other Christians.

\section{Fol. 79v}

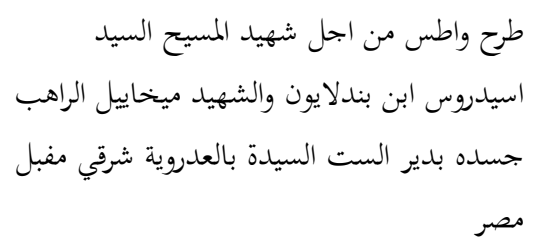

dM(DINI THPOY NIAdOC 'MMdINOY† $\overline{\mathrm{in}} \overline{\mathrm{C}} \Pi \overline{\mathrm{X}} \overline{\mathrm{C}}$ 'ntentalo 'mnampi marioc KYPIOC ICLAOPOC

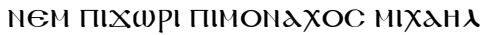

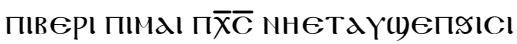
'nnibacanoc eөве ПIран 'ndГd $\theta$ OC

OYO2 'nTEN(D) EвOג PHTOC $x \in$

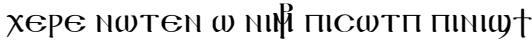

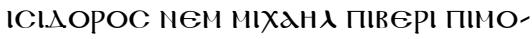
NAXOC

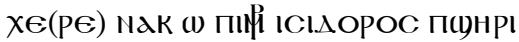

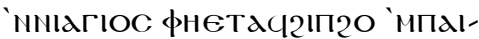
космос nем тесMетоYро єөме2 'мпдөос

хере ПINIC† пाдекүтнс мІханג

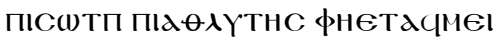

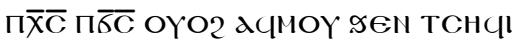
ехем †неөмн
Tarh Batos for the martyr of Christ, master Isidore son of Panteleon and the martyr Michael the monk. His body is buried in the Monastery of the Lady and Virgin in Adawia on the east bank in front of Old Cairo

Come all God-loving people in order to honour these martyrs, the saintly master Isidore

And the mighty monk Michael the New, the lover of Christ who suffered tortures for the sake of His good name

And let us sing also: "Hail to you (pl) $\mathrm{O}$ martyrs, the chosen great Isidore and the monk Michael the New

Hail to you, O Martyr, Isidore the son of the saints, for he rejected this world and its kingdom that is full of sufferings

Hail (to) the great ascetic Michael the chosen athletic who loved Christ the Lord and died by the sword for the sake of the truth 


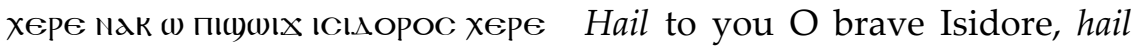

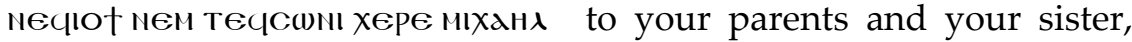
пирєсбро фнетдс ${ }^{53}$ hail (to) Michael the Victorious who...

\section{Fol. 22}

مرد الانجيل بطريقة الشعانين

Mapenzwc en $\bar{x} \bar{c}$ nennoy† sen

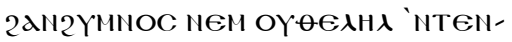

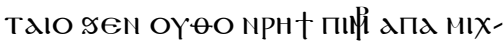
$\mathrm{dH \lambda}$

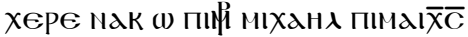

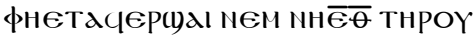
gen tXopd 'nTE NIETUN.

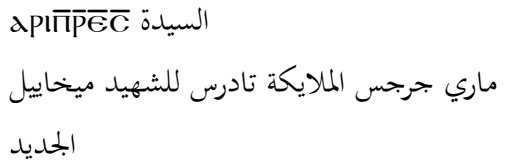

$x \in$ clomd

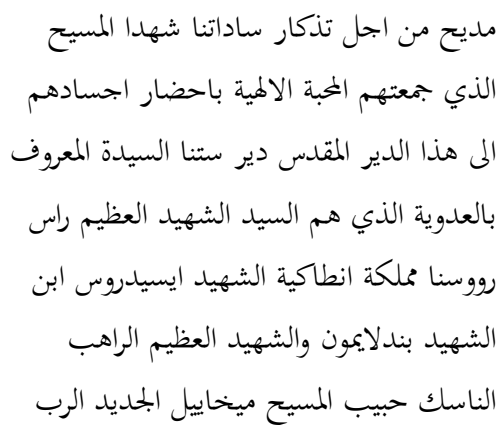

Response to the Gospel to the tune of the Palm Sunday:

Let us sing to Christ our God with hymns and joy and let us honour in many ways the martyr Apa Michael

Hail to you O Martyr Michael the lover of Christ who rejoiced with all the saints in the land of the living

Intercede (for us) Lady (Mary), Saint George, the angels, Theodore, to the martyr Michael the New.

For He is blessed (Youhanna - this sentence is really weird. It's asking St Mary etc to pray to Michael for he is blessed? The only person we or saints pray to is God, not another person or saint. Seems a bit heretical to me.)

A hymn for the commemoration of our masters the martyrs of Christ who were united in divine love and the translation of their bodies to this holy Monastery of our Lady and Virgin known as al-'Adawi. They are the great master and martyr and greatest in the kingdom of Antioch, Isidore son of the martyr

(53) The scribe forgot to complete the word. 
يجعل لنا معهم ميراثا ونصيبا في يروشليم * السمايية امين

تعالوا جميعاً ايها الشعوب محبي الاله يسوع المسيح لنسجد لثالوث المقدس ونمجدك بالاغاني والتراتيل الروحانية من اجل التذكار

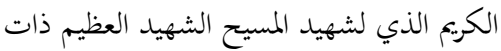
النسب الكريع والجنس العظيم السيد ايسيدروس

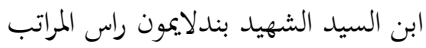
والطقوس بالمملكة المعظمة انطاكية والشهيد المكرم الراهب العابد محب المسيح ميخاييل الجديد الذي صار من اصحاب الساعة الحادية عشر من اجل اعترافه الحسن امام الملك وكل

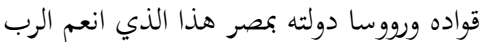
علينا اولاد هذا الدير المقدس باحضار جسدهم الذي صار فرحا وعز الكل القاصدين اليه

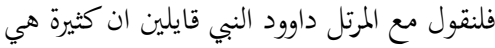
احزان الصديقين ومن جميعها يخلصهم الرب فربان

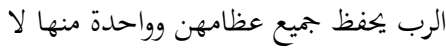
تتلف*

لقد فرحت كورة مصر ولاسيما بزيادة اولاد المجمع المقدس بحلول جسدكم المكرم بينهم

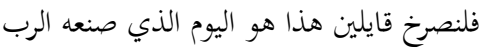

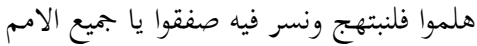

Panteleon and the great ascetic martyr-monk, the beloved of Christ Michael the New. May God make us share an inheritance with them in the heavenly Jerusalem. Amen!

So come, O Christ-loving people, in order to worship the Holy Trinity and to praise with songs and spiritual hymns in honour of the commemoration of the martyr of Christ, the great martyr, who is from a noble family and great race, master Isidore the son of the lord martyr Panteleon, who is the highest of ranks in the great kingdom of Antioch, together with the honoured martyr, the lover of Christ, Michael the New, who in the eleventh hour gave his good confession before the king and his principals and the leaders of his government in Egypt. By bringing their bodies to this holy Monastery of which we are children, the Lord has granted us joy and happiness for all who come to Him. Let us say with the Psalmist David the Prophet: "Many are the afflictions of the just, the Lord will deliver them from them all. The Lord will guard their bones: not one of them will be broken. ${ }^{54}$

The land of Egypt rejoiced, especially the children of this holy congregation by the arrival of your honoured bodies. Let us sing and praise saying: "This is the day that

(54) Ps. 33(34):19-20. 


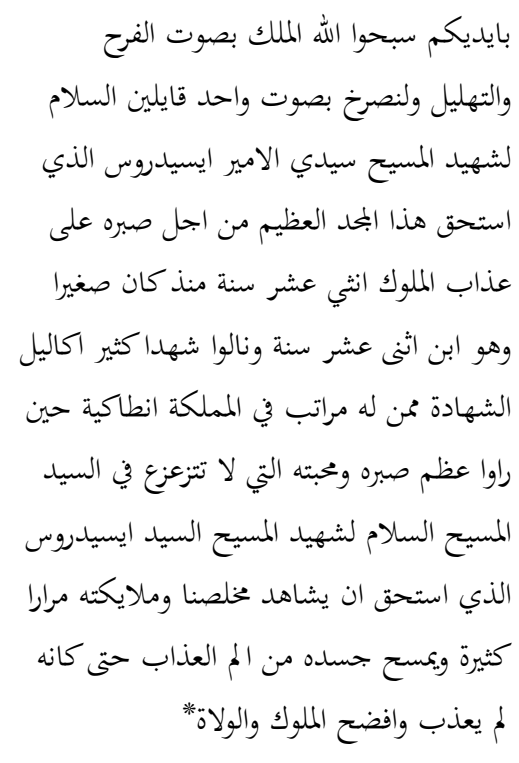

السلام لشهيد المسيح وحبيبه المكرم ايسيدروس

الذي مات دفوعا كثيرة من قبل العذاب الذي قبله من الملوك والسيد المسيح يقيمه حتي صاروا جميع اجناد المملكة وكل الشعوب داهشين ومتعجبين من صبره وجهاده ولا سيما عندما ينظروا الى صغر سنه وعظم مرتبته في الامريه وعلو منزلته السلام للذي خرج للقاه عند وقت

اخذ راسه جميع طقوس السما والشهدا والصديقين السلام لشهيد المسيح ذات الاسم the Lord has made, let us rejoice and be glad in it." 55 "All nations clap your hands; shout aloud to God with a joyful and happy voice." 56 Let us sing with one voice saying: "Hail to the martyr of Christ, my lord and prince Isidore who became worthy of this great glory because of his patience in tortures inflicted by the kings at the age of twelve years since his childhood, at the age of twelve year. Many of high rank in the kingdom of Antioch received crowns of martyrdom when they saw his great patience and his unshakable love in the Lord Christ. Hail to the martyr of Christ, lord Isidore who became worthy of seeing our Saviour and His angels many times when they came to heal his body from the sufferings of the tortures and he was restored as whole. He put to shame the kings and rulers.

Hail to the martyr and beloved of Christ, the honoured Isidore, who died several times through the tortures inflicted by the kings, and the Lord Christ resurrected him. The soldiers of the kingdom and all the people were amazed and marvelled at his patience and his struggle, especially when they saw his young age and noble rank. Hail to those who came to greet him at the time of his beheading, all the hea-

(55) Ps 118.

(56) Ps 46:2. 
المكرم ايسيدروس ابن الشهدا الذي فاز بالخيرات الديمة ونال الاكاليل النورانية السمايية الذي لا يستطيع لسان جسداني يصف يسير من كرامتهم السلام لحبيب المسيح العابد المجاهد الشهيد مخاييل الجديد الراهب المتوشح بالاسكيم المقدس الذي كمل عليه قول القايل

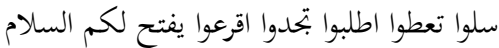

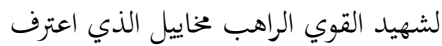
حسنا الاعتراف الحسن امام الملك وكان

عظما مملكته والحكام جهر قايلا اني اخترت

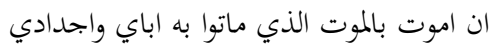

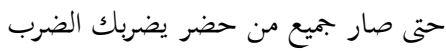

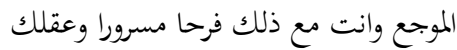
مرتفعا الى فوق منتظر السعادة الابدية السلام

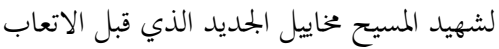

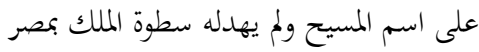

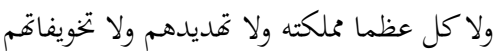
حتي تعجبوا من قوة شجاعته السلام لميخاييل الراهب والشهيد الذي فاز بالحياة الابدية

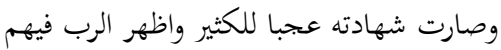
قوة عجاييه السلام لجسدك الطاهر الذي جدد venly ranks, the martyrs and the just ones. Hail to the martyr of Christ who has the honoured name Isidore, the son of the martyrs who attained the everlasting reward, and received heavenly crowns of light that no earthly tongue is able to describe even a fraction of their honour. Hail to the beloved worshipper of Christ, the victor and martyr Michael the New, the monk who wears the holy skhêma, of whom was accomplished the saying: "Ask, and it shall be given you; seek, and you shall find; knock, and it shall be opened unto you." ${ }^{57}$ Hail to the mighty martyr the monk Michael who confessed the good confession ${ }^{58}$ before the king and all the great ones of his kingdom and the rulers saying: "I chose to die from the death that my fathers and my grandfathers died from. All those in attendance created great havoc, whereas you were happy and joyful. Your mind was elevated, looking forward to the coming eternal happiness. Hail to the martyr of Christ, Michael the New, who endured sufferings for the sake of Christ's name. He felt neither threaten by the authority of the king and all the great ones of his kingdom nor (was he swayed by) their menace and terror. So they

(57) Mt 7:7.

(58) Abd al-Masih SALiB, піхшм 'nте пाєүхологіоn єөоүaв [The Book of the Holy Euchologion], Cairo, 1902, p. 407. 
الفرح في كورة مصر اسالوا الرب من اجلنا يا

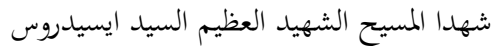

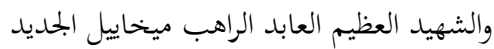

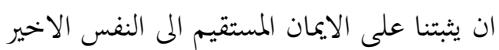

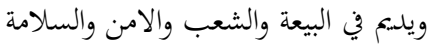

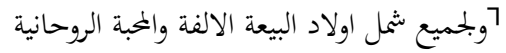

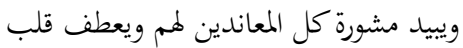
السلطة المعظمة وكل اوليا الامور وينظر برحمته

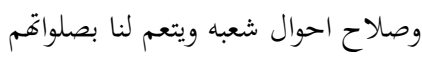
امين

\section{SUMMARY}

This article presents for the first time liturgical texts relating to a new martyr. In addition, it contributes to our knowledge of the Mamluk period, while shedding new light on the history of the church of the Virgin Mary in Ma'adi. were amazed by his might and courage. Hail to Michael the monk and martyr who won eternal life and his martyrdom became amazing to many. The Lord revealed to them great miracles. Hail to your pure body that renewed happiness in the land of Egypt. Pray to the Lord for us, O martyrs of Christ, the great lord Isidore and the great martyr Michael the New, so that He may confirm us in straight faith to the last breath and grant security and peace forever for the Church and people. And let the children of the Church be charitable and have spiritual love and let Him disperse all those who oppose them. Let Him soften the hearts of the great authorities and those governing and let Him look upon His people with His mercy and His goodness and let Him grant us (a place with Him) through their prayers. Amen! 

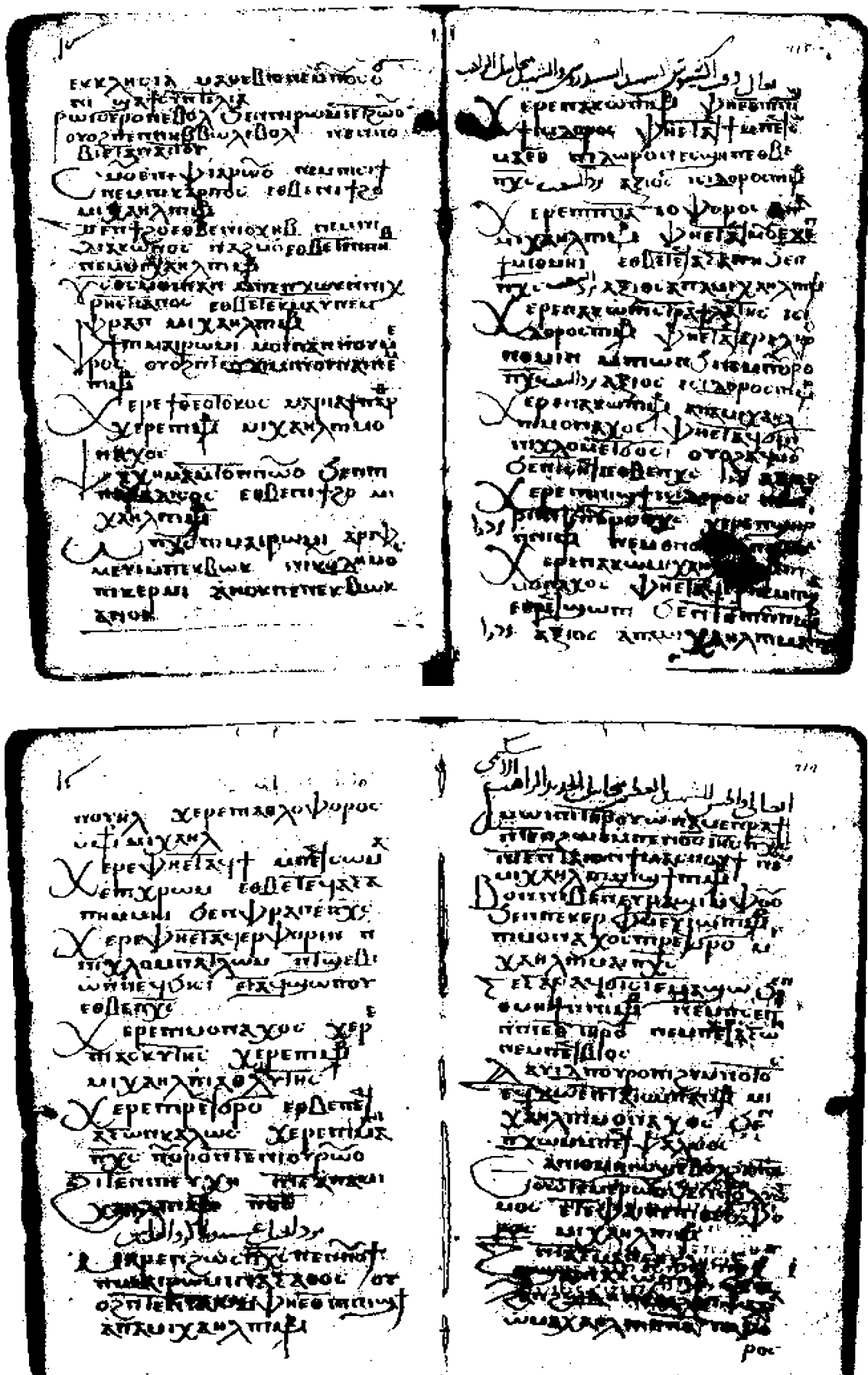

\& $\frac{5}{19}$

y

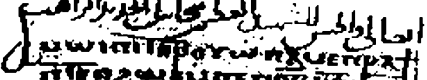
TWT

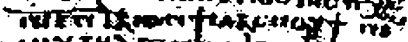

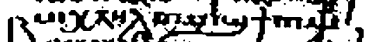

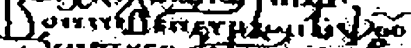

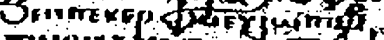

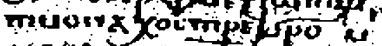
$x$ andincixing

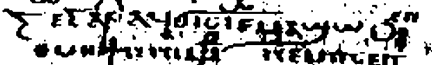

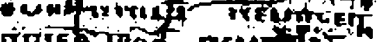

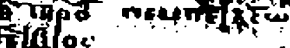

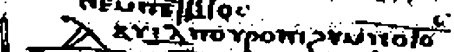

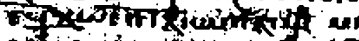

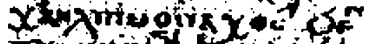

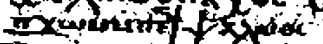
$=$ inrogin , क्या कर

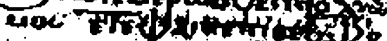

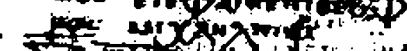

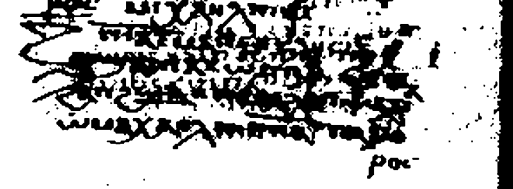

